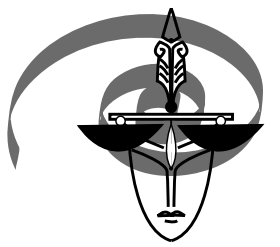

\title{
EUROPEAN
}

Volume $8 \cdot 2014 \cdot$ Number 1 (27)

DOI: 10.2478/ep-2014-0003

Karolina Dukała, Romuald Polczyk Institute of Psychology, Jagiellonian University

\section{Value of Content-Based Deception Detection Methods}

Key Words: detection of deception, content-based methods, CBCA, Reality Monitoring

Literature abounds with examples of various methods serving detection of deception in testimonies. They can be divided both according to the methods used depending on the tactics of witness interrogation (Gruza, 2009) and the psychological model of analysing testimony veracity (Marten, 2012). Functioning currently is also a division of methods of detecting deception based on the channel of communication analysed (Vrij, 2008): methods based on the analysis of the so-called non-verbal and vocal detection of deception (DePaulo et al., 2003), methods based on psychophysiological analyses (polygraph, EEG, fMRI, and thermography examinations), and methods that analyse the contents of the testimony (e.g. Content Based Criteria Analysis - CBCA,

"romuald.polczyk@uj.edu.pl 
Steller, Köhnken, 1989; Reality Monitoring - RM, Sporer, 2004; Aberdeen Report Judgement Scale - ARJS, Sporer, Breuer, 2009). The last set of tools seems to be most interesting for the potential of an extensive application in judiciary practice, and relative easiness and low cost of application, coupled with powerful theoretical grounds (Wojciechowski, 2012).

In the past, studies related to the last group of the methods focused mostly on seeking an answer to the question whether it is possible to find elements proving that witness testimony was consciously falsified in its content, and what elements these are. Today, it is rather assumed that the above is possible, and psychologists' efforts aim at building a classification of such elements mostly in the form of the so-called veracity criteria, whose presence in a testimony proves its sincerity. The methods that are based on analysing testimony content are often called verbal veracity assessment tools (Vrij, 2005), as they analyse the contents of the witnesses' statements, with omission of vocal (e.g. pitch of the voice, pauses in the utterance, etc.) and non-verbal (gestures, leg movements, etc.) hints.

What is usually used as theoretical grounds for the existence of content-based methods is the so-called Undeutsch hypothesis: the assumption that a testimony based on the witness's personal experience differs in form and content (qualitatively and quantitatively) from deceptive or insincere testimonies, and that the motivation of the liar is different than that of a person telling the truth, which translates into the contents of the testimony (Arntzten, 1989).

It is also noted that, according to the Reality Monitoring model (Johnson, Raye, 1981), memories of actual events differ in content and quality from representations and false memories. True memories about actual, personal experiences mirror the processes of perception that take place during their acquisition, while the ones based on representations contain more inference and cognitive processes. It was empirically proved that memories of experiences contain more stimuli data (visual detail, sounds, tastes, physical sensations), and contextual and emotional information than false memories (Johnson and Raye, 1981). Basically, the model explains how true memories "mix" in memory with fabricated events (or implied memories). Nevertheless, researchers adapted it to the needs of building a tool for discovering deceptive statements (Sporer, 2004, Alonso-Quecuty, 1992).

Currently, psychological literature distinguishes at least a number of systems of assessing testimonies and several dozens of criteria of veracity (see e.g.: Arntzten, 1989; Adams, 1996; Dando, Bull, 2011; Akehurst, Köhnken, Hoefer, 
2001). The system that is perhaps most frequently used in the judicial practice is the Content Based Criteria Analysis - CBCA (e.g. Vrij, 2005, Köhnken, Steller, 1989). It is a tool that makes up a part of a larger procedure known as Statement Validity Analysis (SVA). It consists of 19 criteria concerning the semantic features of the contents of a testimony which, following the hypotheses, emerge more frequently in sincere testimonies (i.e. of events the person actually witnessed) than in deceptive (concerning invented events). These criteria include "logical structure" (criterion 1), "lots of details" (criterion 3), and "description of interactions" (criterion 5). It is assumed that in true testimonies, these criteria are present with greater intensity than in false ones. In other words, in sincere testimonies, people trained in the use of the CBCA method should confirm the existence of a logical structure of the utterance more often, diagnose a greater number of details, and discover the existence of utterances or parts of conversations quoted in the original form more often than in false testimonies.

Another system to be fairly well described in literature is Reality Monitoring (RM), based on a model quoted above (Johnson, Rye, 1981). The tool consists of 8 or 7 (see: Sporer, 2004;Vrij, 2008; Sporer, 1997) or 43 criteria (SMCQ, Sporer, Kuepper, 1995) divided into eight sections, and including, for example "visual details", "spatial details", "emotion" (Sporer, 1997).

Studies using content-based methods traditionally include three indicators: total accuracy rate, accuracy rate in diagnosing true statements (colloquially speaking: the capacity of a tool for revealing true statements as true), and the accuracy rate in pointing to false statements. These indicators differ in scientific studies (both experimental and practical), yet studies prove that the total accuracy rate of the CBCA usually oscillates between 55\% (Granhag, Strömwall, Landström, 2006) and 100\% (Esplin, Boychuk, Raskin, 1988), and in the case of the RM - between 61\% (Sporer, Sharman, 2006) and 82\% (Stromwall, Granhag, 2005). Falling back on the literature concerning matters of deception, Vrij (2008) sets the average accuracy rate of CBCA at $70.81 \%$, and that of RM - at $68.8 \%$. This allows to notice that the distribution of results concerning the accuracy rate of content-based methods is significant, and amounts nearly to $50 \%$, depending on the experiment. Therefore, a question where such a difference originates arises: what variables influence the efficiency of content-based methods, and in consequence - differences between the studies.

An important question concerning the calculation of accuracy rate of content-based tools must be emphasised here. Analysis of sincerity conducted 
with such a tool is usually performed in two phases. In the first, the coder of $\mathrm{CBCA}, \mathrm{RM}$, or other method is looking for the criteria of veracity in a given statement, and later assigns to them point-based values. Usually, a 0 if the given criterion is absent, 1 - if it is present in low intensity, and 2 if it is very clearly present. A five-point (e.g. Godert et al., 2005) and a seven-point (e.g. Bradford, 2006) scale can also be used. To perform the calculation of the accuracy rate of a given method at this stage, some researchers employ statistical analyses (i.e. Multiple Discriminant Analysis) comparing the numbers of points acquired in truthful statements to the sums of points scored by false testimonies. It must, however, be strongly emphasised that the method does not apply in judicial practice, as courts experts do not have at their disposal multiple true and false statements, on whose grounds they could run statistical analyses. Everyday situations include also the second phase of the analysis: using a given tool, the coder must independently assess whether he or she believes the statements to be true or false. It is worth mentioning that content-based tools do not have objectively set limits defining the number of points above which a statement or testimony is true. According to the theory, the only thing that can be ascertained with such a tool is the fact that the greater the number of the points, the greater the probability that the testimony is true. The coder (court expert in practice) must himself or herself make the decision whether - on the power of own experience, the veracity criteria found, and knowledge of the tool - the testimony in their opinion is false or true. Some published studies measure the accuracy rate of a tool on the grounds of the coders' own true - false assessments made after conducting CBCA or RM analysis. The differences between this indicator of accuracy rate and the first one (i.e. calculated from the significance of the difference between the number of points acquired in true and false statements) may be significant and differ even by several persent for the same testimonies and the same coder (Dukała, Sporer, Polczyk, in print). The reason for such a status quo can most probably be the fact that while making the final decision whether testimony is true or false, coders working on content analysis do not follow the number of diagnosed criteria but rather their subjective weights.

Thus, one of the variables that influence differences in the efficiency of content-based tools of detecting deception in testimonies is the method of calculating the accuracy rate of the tool. Besides the above, researchers point to the existence of variables related to the persons of the witness and the interrogator, and the event itself. It is generally believed that these are usually such variables that have an impact on the quality of the statements made (Vrij, 2005). For if a statement is sparing, short, forced, and/or contains a very 
small number of details, it is far more difficult to ascertain the presence of criteria of its veracity, which may disrupt CBCA and RM analyses. In turn, if a statement is extensive, and the free utterance of the witness is complex and rich, there is a greater probability for the criteria of veracity two emerge, which has an impact on the accuracy rate of content-based methods.

One of such important variables is the age of the interrogated. CBCA was designed to verify the veracity of children's statements in cases related to sexual abuse, hence the presence of some specific criteria (e.g. the criterion 10 "accurately reported details misunderstood", being a criterion concerning especially sexual performance, which a small child does not understand yet can describe them well, if he or she is actually their witness or a victim). Nevertheless, Undeutsch's hypothesis on which CBCA is based concerns general motivation and cognitive mechanisms in the human. Hence, it can be expected that the tool will be efficient both in the case of children and adults. However, some specialists draw the conclusion that if CBCA was designed to cover testimonies of children, the efficiency of the entire tool may be the same in the case of testimonies of children and adults, yet some of the criteria will turn up only and solely in the testimonies of children, and not in those from the adult people (e.g. the criterion 10 mentioned above). Additionally, small children are not fluent in expressing themselves, and building utterances and sentences, which may influence the quality of a testimony, and indirectly - the accuracy rate of the tools.

In turn, RM is based on theories concerning monitoring, i.e. a cognitive process that is developed and mature in adults. As the authors of the Reality Monitoring theory (Johnson, Rye,1981) themselves note, this processes is not yet developed in children, and children relatively frequently happen to confuse events they invented with ones that actually occurred to them. It can, therefore, be assumed that a tool serving verification of sincerity of the testimonies based on the criteria made on the grounds of the theory will have a lower efficiency in the case of children's testimonies than in the case of the ones acquired from adults.

Studies of CBCA accuracy rate suggest that generally the presence of the CBC a criteria is related to the age of the testifying person (Buck, Warren, Betman , Brigham, 2002; Craig, et al., 2000; Hershkowitz, Lamb, Sternberg, Esplin, 1997; Lamers-Winkelmann and Buffing, 1996; Santtila, Roppola, Runtti, Niemi, 2000; Vrij, Akenhurst, Soukara, Bull, 2002). In other words, testimonies of younger children contain fewer CBCA criteria (or criteria are discovered, yet with low intensity) than testimonies of older children and adults. For 
example, studies conducted by Buck and the team (Buck et al., 2002) discovered that the presence of no fewer than 13 criteria was correlated with age. Probably this is why CBCA accuracy rate in case of children's testimonies is slightly lower than in the case of adult testimonies (Vrij, 2005), yet only up to a certain age, approximately 9 years (Santilla et al., 2000). This, as a rule, is explained by the fact that younger children still find it difficult to assume the perspective of other people (hence absence of certain criteria, e.g. "pardoning the perpetrator" in their testimonies). Additionally, some researchers (notably Craig, Sheibe, Rasklin, Kircher, Dodd, 1999; Davies, Westcott, Horan, 2000) notice that in the case of younger children, the interrogators usually do not allow free utterances and use large numbers of leading (direct) questions, if not even focused ones. This results in low quality, short testimonies, and sparing input from children, which in turn may have a negative bearing on the efficiency of the CBCA in reference to the testimonies of small children. It must, however, be noted that in some studies, the impact of the age on the accuracy rate CBCA is not present (Akenhurst, Köhnken, Hofer, 2002).

A similar result is acquired when RM analyses is applied. For example, the studies by Otgaar, Candel, Memon, and Almerigogra (2010) did not acquire a satisfying accuracy rate in the use of RM for distinguishing between true and invented statements of young children, although one of the criteria (visual details) was distinctive for the difference between true and false statement well. In turn, other studies allow to draw a conclusion that RM works well only in the case of statements from adults (e.g. Sporer, Kuepper, 1995, Sporer and Sharman, 2006) and older children (Santtila, Roppola, Niemi, 2000; Stromwall, Granhag, 2005). In turn, for example, studies conducted by Roberts and Lamb (2010) ascertained that the older the child, the more RM criteria are present in his or her testimonies, and the effect was far more stronger in the case of true statements, then the false ones. Generally, it can therefore be stated that in the case of very young children, content analyses are hardly efficient in differentiating between true and false testimonies, yet the efficiency grows parallel to the age of the child.

Another important variable is the level of training of the people who use content-based methods. One could expect that the better trained (or having a longer experience) CBCA coder, the better diagnosis of the presence of individual criteria and the more accurate the conclusions drawn from the analyses conducted. In the case of CBCA, the recommended training lasts 3 weeks (Köhnken, 1999) or at least 3 days (Raskin and Esplin, 1992). Unfortunately, published scientific articles contain hardly any information on 
the training for RM and CBCA coders. As a rule, researchers disregard the question entirely while describing the method. And yet, as research concerning e.g. efficiency of lie detection methods based on non-verbal signals, not only is the length of training significant, but so are the number of analyses performed earlier in a given method and the number of articles read (see: Vrij, 2008).

In the case of $\mathrm{CBCA}$, there are at least a number of studies comparing the accuracy rate of detecting deception by untrained and trained people applying CBCS. The results of the studies are contradictory. In some studies, the training in applying $\mathrm{CBCA}$ helped to increase the accuracy rate of coders compared to an untrained population (Landry \& Brigham, 1992; Vrij, Kneller, Mann, 2000; Fiedler \& Walka, 1993; Porter, Yuille, Lehman, 2000, Tye et al., 1999), in others, it reduced it (Akehurst et al., 1998), and yet in others no difference in the accuracy rate of finding insincere statements between trained and untrained coders was discovered (Ruby \& Brigham, 1998; Santtila et al., 2000). However, attention should be paid to the fact that majority of cases covered by the studies referred to above lasted for 45 minutes (e.g. Landry and Brigham, 1992), 90 minutes (e.g. Ruby and Brigham, 1998) or (a single case) two hours (Akehurst et al., 1998). As Köhnken (2004) noted, such a short time is absolutely insufficient for CBCA coders to be able to learn the method even superficially. Moreover, in most of the studies mentioned above, the training of CBCA coders did not cover an opportunity to practice the skills, and the statements used to analyse veracity were relatively short (e.g. 2 minutes in a study by Ruby and Brigham, 1998). In only one study, an extremely intensive CBCA and RM training was applied, with each coder being given 40 testimonies to assess under the supervision of a specialist and several scientific articles on CBCA and RM to read before the study; Sporer and Bursh, 2003), which significantly increased the accuracy rate of assessments using the methods. On the grounds of these studies and experiments proving zero efficiency rate of CBCA applied by untrained people (e.g. Bradford, 2006), researchers are likely to say that an appropriately long and well-designed training helps to increase the accuracy rate of deception assessments made with the use of CBCA.

As has been mentioned earlier, another very important variable that has an impact on the accuracy rate of content-based methods is the way of conducting the interrogation. Researchers pay attention to the fact that the longer and the freer the expression (free recall) of the witness, the more criteria of veracity can find their way into the testimony. A particular conclusion may be 
drawn from here, namely that the less directive the interrogation, the greater freedom of expression the witness is allowed, and the more encouraging to speak the interrogation is on the other hand, the greater the precision of the CBCA and/or RM. For example, Herskowitz, Lamb and Sternberg (1997) realised that if open questions predominate in an interrogation of children, more $\mathrm{CBCA}$ criteria are present in sincere testimonies than in a situation where mostly focused questions are asked. A similar effect in the case of testimonies from sexually abused children was obtained by Craig, Sheibe, Rasklin, Kircher and Dodd (1999) who additionally noticed that when open questions were answered, more $\mathrm{CBCA}$ criteria emerged in true statements than in false ones (i.e. in the testimonies of children that lied about being sexually abused). In Vrij, Mann, Kristen and Fisher (2007), an accusatory style of interrogation, applied by police officers as a standard practice towards the suspects, significantly decreased the efficiency of both CBCA and RM. In turn, in the studies of Santtila, Roppola, Niemi (2000), a friendly or unfriendly way of interrogating a child influenced the frequency of emergence of CBCA criteria, and consequently - the accuracy rate of the tool.

In literature on the psychology of witness testimonies, cognitive interview (CI) is frequently mentioned as the most efficient technique and one most recommended for interrogating children and adults. Cognitive interview is based on memory, social, and representational techniques (Fisher, Geiselman, 1992). It is used ever more commonly in the daily work of police and prosecution (Memon, Meisner, Fraser, 2010). A question arises whether the application of the technique of interrogation will have an impact on the efficiency of content based tools for detecting insincere testimonies. Researchers point to two possible relations. First, according to the magnifying glass hypothesis (Hernandez-Fernaud and Alonso-Quecuty, 1997), a cognitive interview may increase the differences between true and false testimonies. These experts point to the fact that because a cognitive interview facilitates drawing details from memory, its application will make the statements of the people telling the truth longer, richer in detail, and more transparent, so that the presence of veracity criteria will increase. In turn, a cognitive interview in no way influences the testimonies of the people who lie, because in their case there are no memories, whose drawing would be facilitated by the cognitive interview. In this way, with the application of the CI the difference between true and false testimonies becomes highly visible, which facilitates the operation of content-based methods. 
Another hypothesis (Dukała, Sporer, Polczyk, in print) concerns the representational aspect of cognitive interview techniques. Many elements in such interrogations concern encouraging the witness to imagine the circumstances of the event, involving all senses in reminding, engaging imagination, and reporting the greatest number of details (e.g. probing images, context reinstatement techniques). Such a procedure may help deceptive individuals to build a more probable lie during an interrogation than in the cases when traditional form of interrogation is applied. In this way, the CI may negatively influence the efficiency of content-based techniques.

The results of studies in this area are not coherent. For example, the application of cognitive interview decrease the efficiency of RM in the studies conducted by Bembibre and Higueras (2011), and especially so in the case of testimonies concerning false accusations. Steller and Wellershaus (1996) observed a major drop in CBCA accuracy rate in the case of false testimonies collected with the use of cognitive interview as compared to the testimonies acquired during a standard interrogation. Although the studies conducted by Köhnken, Shimossek, Ashermann, Hoffer (1995) did not corroborate the impact of the manner of interrogation on the general accuracy rate of $\mathrm{CBCA}$, yet it was observed that some $\mathrm{CBCA}$ criteria emerge more frequently in true and false statements acquired during a cognitive interview than in ones acquired during a standard interview (SI). Observed in the studies by Landstrom and Garnhag (2005) was the fact that certain RM criteria (temporal, spatial information) emerge more often in false statements acquired in CI than in SI. In turn, no negative impact of CI on the presence of RM criteria was observed in Hernandez-Fernaud and Alonso-Quecuty (1997). The results of the studies quoted above point to the fact that a cognitive interview may have a bearing on the efficiency of content-based techniques, yet this area has not been fully researched yet.

What has additional impact on the efficiency of content-based methods is the number of interrogations. For example, Saykaly (2009) observed that the presence of $\mathrm{CBCA}$ criteria decreases and altogether disappears at the third interrogation of a child. Erdmann, Volbert and Bohm (2004) noticed that in the fifth interrogation of a child, only one CBCA criterion (quantity of details) differentiates true statements from false, and additionally some children begin to believe that they witnessed an event that never happened already after the fourth interrogation. Granhag, Stromwall and Landstrom (2006) observed a similar impact on RM in the case of five consecutive inter- 
rogations. In turn, Stromwall, Granhag, (2005) observed that the accuracy rate of RM in reference to the testimonies of all the children decrease already after the second interrogation.

One of the variables that have an impact on the efficiency of content-based techniques is the training of the person making the insincere testimony. Researchers pay attention to the fact that a person familiar with the criteria of veracity may include them into their statement while lying, in this way reducing the efficiency of content-based tools. A number of experiments were conducted to verify the claim. It found corroboration both in the case of testimonies of children (Vrij, Akenhurst, Soukara, Bull, 2004; Vrij, Keller, Mann, 2000; Vrij, Akenhurst, Soukara, Bull, 2002) and adults (Caso, Vrij, Mann, De Leo, 2006).

Additionally, experts point to the personality-based variables of a witness that may have an impact on the efficiency of content-based tools. These include fantasy proneness (with people with high fantasy proneness being capable of creating convincing and colourful lies that reduce the efficiency of CBCA; Schellerman-Offermans, Merckelbach, 2010), verbal skills (the higher they are, greater number of CBCA criteria turn up in testimonies independent of their veracity; Santtila, Roppola, Niemi, 2000), social anxiety (decreases the quality of the testimony and reduces the efficiency of both CBCA and RM; Vrij, Akenhurst, Soukara, Bull, 2004), and social adroitness (the presence of this trait in a witness increases the efficiency of the CBCA; Vrij, Akenhurst, Soukara, Bull, 2004). It must, however, be mentioned that studies concerning the links between the personal traits of the witness and the efficiency of content-based methods mentioned above have not been replicated.

Moreover, one should pay attention to the fact that the nature of a memory may influence the efficiency of content-based methods. The researchers strongly emphasise that both CBCA and RM were created to differentiate between sincere and deceptive testimonies, and account for the witness's intentions, as the variables that is responsible for creating differences between these types of statements (e.g. Köhnken, Steller, 1989). These tools may prove inefficient in statements based on suggested or false memories, in whose case, the witness is convinced about their authenticity. The results of studies do not corroborate the hypothesis. For example, Blandon-Gitlin, Pezdek, Lindasy and Hagen (2009) studied the testimonies of people who had a false memory concerning a childhood event (e.g. getting lost in a shopping centre, upsetting a punch vase at a party) developed. Analyses with the use of CBCA and RM distinguished true statements from ones based on false memories, 
yet only if the false memory was defined as partial. In Short and Bonder (2010) RM in the 43-criteria version also proved efficient in distinguishing between true and suggested statements, yet the effect was not strong.

Content-based methods of discovering deceptive testimonies gain on popularity both in Poland (Wojciechowski, 2012) and in other European states (Vrij, 2008) due to the easiness of application and relatively high accuracy rate. Their vast advantage is the fact that there are plenty of well-conducted studies concerning the factors that influence the efficiency of these tools, which makes it possible to use them more precisely, and correctly in practice. It is, however, material to remember that certain areas concerning the factors resulting from the analyses using content-based methods (e.g. the personal traits of a witness, and the impact of the manner of interrogation) still require additional studies.

\section{References}

Adams S.H. (1996), Statement analysis: What do suspects' words really reveal? FBI Law Enforcement Bulletin, October, 12-20.

Akehurst L., Bull R., Vrij A., Koehnken G. (2004), The effects of training professional groups and lay persons to use Criteria - Based Content Analysis to detect deception. Applied Cognitive Psychology, 18, 877-891.

Akehurst L., Koehnken G., Hoefer E. (2001), Content credibility of accounts derived from live and video presentations. Legal and Criminological Psychology, 6, 65-83.

Alonso-Quecuty, M. L. (1992). Deception detection and reality monitoring: A new answer to an old question? In F. Lösel, D. Bender, \& T. Bliesener (Eds.), Psychology and Law. International Perspectives (328-332). Berlin: Walter de Gruyter.

Arntzen F. (1989), Psychologia zeznań świadków. Państwowe Wydawnictwo Naukowe, Warszawa.

Bembibre, J., \& Higueras, L. (2011). Differential effectiveness of the cognitive interview in a simulation of testimony. Psychology, Crime E Law, 17, 473-489.

Blandón-Gitlin, I., Pezdek, K., Lindsay, S.D., \& Hagan, L. (2008). Criteriabased content analysis of true and suggested accounts of events. Applied Cognitive Psychology, 23, 901-917. 
Bradford, D. (2006.) Detection of deception in the confessional context. Unpublished doctoral dissertation. University of New South Wales.

Buck, J. A., Warren, A. R., Betman, S. I., \& Brigham, J. C. (2002). Age differences in Criteria-Based Content Analysis scores in typical child sexual abuse interviews. Journal of Applied Developmental Psychology, 23, 267-283.

Caso, L., Vrij, A., Mann, S., \& de Leo, G. (2006). Deceptive responses: The impact of verbal and nonverbal countermeasures. Legal and Criminological Psychology, 11, 99-111.

Craig, R. A., Scheibe, R., Raskin, D. C., Kircher, J. C. \& Dodd, D. (1999). Interviewer questions and content analysis of children's statements of sexual abuse. Applied Developmental Science, 3, 77-85.

Dando. C. J., Bull, R. (2011). Maximising opportunities to detect verbal deception: Training police officers to interview tactically. Journal of Investigative Psychology and Offender Profiling, 8, 189-202.

Davies, G. M., Westcott, H. L., and Horan, N. (2000), The impact of questioning style on the content of investigative interviews with suspected child abuse victims, Psychology, Crime and Law, 6, 81-97.

DePaulo, B. M., Lindsay, J. J., Malone, B. E., Muhlenbruck, L., Charlton, K., \& Cooper, H. (2003). Cues to deception. Psychological Bulletin, 129, 74-118.

Dukała, K. Sporer, S., Polczyk, R. (in preparation). Can Cognitive Interview Impair Lie Detection Using CBCA Criteria in Elderly Witnesses Testimonies?

Erdmann, K., Volbert, R., \& Bohm, C. (2004). Children report suggested events even when interviewed in a non-suggestive manner: What are its implications for credibility assessment? Applied Cognitive Psychology, 18, 561-589.

Esplin, P. W., Boychuk, T., \& Raskin, D. C. (1988, June). A field study of criteria-based content analysis of children's statement in sexual abuse cases. Paper presented at the NATO Advanced Studies Institute on Credibility Assessment, Maratea, Italy.

Fiedler, K., \& Walka, I. (1993). Training lie detectors to use nonverbal cues instead of global heuristics. Human Communication Research, 20, 199-223.

Fisher, R.P, \& Geiselman, R.E. (1992). Memory enhancement techniques for investigative interviewing: The cognitive interview. Springfield, IL: Charles C. Thomas. 
Godert, H.W., Gamer, M., Rill, H.G., \& Vossel, G. (2005) Statement validity assessment Inter-rater reliability of criteria-based content analysis in the mock-crime paradigm. Legal and Criminological Psychology, 10, 225-245.

Granhag, P. A., Strömwall, L. A., \& Landström, S. (2006). Children recalling an event repeatedly: Effects on RM and CBCA scores. Legal and Criminological Psychology, 11, 81-98.

Gruza, E. (2009). Psychologia sadowa dla prawników. Warszawa: Oficyna Wolters Kluwer business.

Hernandez-Fernaud, E., \& Alonso-Quecuty, M.L. (1997). The Cognitive Interview and lie detection: A new magnifying glass for Sherlock Holmes? Applied Cognitive Psychology, 11, 55-68.

Hershkowitz, I., Lamb, M. E., Sternberg, K. J., \& Esplin, P. W. (1997). The relationships among interviewer utterance type, $\mathrm{CBCA}$ scores and the richness of children's responses. Legal and Criminological Psychology, 2, 169-176.

Johnson. M. K., \& Raye, C. L. (1981). Reality monitoring. Psychological Review, 88, 67-85.

Köhnken, G. (1999, July). Statement Validity Assessment. Paper presented at the pre-conference programme of applied courses 'Assessing credibility' organised by the European Association of Psychology and Law. Dublin, Ireland.

Köhnken, G. (2004). Statement validity analysis and the 'detection of the truth. In P.A. Granhag, \& L.A. Stro"mwall (Eds.), Deception detection in forensic contexts (41-63). Cambridge, England: Cambridge University Press.

Köhnken, G., Schimossek, E., Aschermann, E., \& Ho"fer, E. (1995). The cognitive interview and the assessment of the credibility of adult's statements. Journal of Applied Psychology, 80, 671-684.

Lamers-Winkelman, F., \& Buffing, F. (1996). Children's testimony in the Netherlands: A study of statement validity analysis. Criminal Justice and Behavior, 23, 304-321.

Landry, K., \& Brigham, J. (1992). The eVect of training in Criteria-Based Content Analysis on the ability to detect deception in adults. Law and $\mathrm{Hu}$ man Behavior, 16, 663-675.

Marten, Z. (2012). Psychologia zeznań. Warszawa: Lexis Nexis. 
Memon, A., Meissner, C. A., \& Fraser, J. (2010). The cognitive interview: A meta-analytic review and study space analysis of the past 25 years. Psychology, Public Policy, E Law, 16, 340-372.

Otgaar, H., Candel, I., Memon, A., Almerigogna, J. (2010), Differentiating between children's true and false memories using Reality Monitoring criteria' Psychology, Crime and Law,16, 555-566.

Porter, S., Yuille, J. C., \& Lehman, D. R. (1999). The nature of real, implanted, and Fabricated memories for emotional childhood events: Implications for the recovered memory debate. Law and Human Behavior, 2, 517-537.

Raskin, D. C. \& Esplin, P. W. (1991b). Statement validity assessment: Interview procedures and content analysis of children's statements of sexual abuse. Behavioral Assessment, 13, 265-291.

Roberts, K., P. \& Lamb, M. E. (2010). Reality-monitoring characteristics in confirmed and doubtful allegations of child sexual abuse. Applied Cognitive Psychology, 24, 1049-1079.

Ruby, C. L., \& Brigham, J. C. (1997). The usefulness of the Criteria-Based Content Analysis technique in distinguishing between truthful and fabricated allegations. Psychology, Public Policy and Law, 3, 705-737.

Ruby, C.L. \& Brigham, J.C. (1998). Can criteria-based content analysis distinguish between true and false statements of African-American speakers? Law and Human Behaviour, 22, 369-388.

Santtila, P., Roppola, H., \& Niemi, P. (1999). Assessing the truthfulness of witness statements made by children (aged 7-8, 10-11, and 13-14) employing scales derived from Johnson and Raye's model of Reality Monitoring. Expert Evidence, 6, 273-289.

Santtila, P., Roppola, H., Runtti, M., \& Niemi, P. (2000). Assessment of child witness statements using Criteria-Based Content Analysis (CBCA): The effects of age, verbal ability, and interviewer's emotional style. Psychology, Crime E Law, 6, 159-179.

Saykaly, Ch. (2009), Effects of Multiple Interview on Children's Verbal Expressive Behaviour of True and Fabricated Events. Unpublished doctoral dissertation, McGill University.

Schelleman-Offermans, K. and Merckelbach, H. (2010), Fantasy proneness as a confounder of verbal lie detection tools. J. Investig. Psych. Offender Profil., 7, 247-260. 
Short, J. L. and Bodner, G. E. (2011), Differentiating accounts of actual, suggested and fabricated childhood events using the judgment of memory characteristics questionnaire. Appied. Cogniive. Psychology, 25: 775-781.

Sporer S.L., Sharman S.J. (2006), Should I Believe this? Reality Monitoring of Accounts of Self - Experienced and Invented Recent and Distant Autobiographical Events. Applied Cognitive Psychology, 20, 837-854.

Sporer, S. (1997). The less travelled road to truth: Verbal cues in deception detection in accounts of fabricated and self-experienced events. Applied Cognitive Psychology, 11, 373-397.

Sporer, S. L. \& Breuer, M. M. (2005). Validity of the Aberdeen Report Judgment Scales-Short Training Version-German (ARJS-STV-G). Paper presented at the annual meeting of the American Psychology-Law Society, TBA, San Antonio.

Sporer, S. L. \& Bursh, S. E. (2003). Training to Detect Deception by Verbal Means: Learning to Discriminate or Change in Response Bias? Unpublished Manuscript, University of Giessen, Germany.

Sporer, S.L. (2004). Reality monitoring and the detection of deception. In P.A. Granhag \& L. Stromwall (Eds.), Deception detection in forensic contexts (64102). Cambridge, UK:Cambridge University Press.

Sporer, S.L., \& Kupper, B. (1995). Realita"tsu"berwachung und die Beurteilung des Wahrheitsgehaltes von Erza"hlungen: Eine experimentelle Studie [Reality monitoring and the judgment of the truthfulness of accounts: An experimental study]. Zeitschrift fur Sozialpsychologie, 26, 173-193.

Steller, M. and Köhnken, G. (1989) "Criteria-Based Statement Analysis", in Raskin, D.C. (ed.), Psychological Methods in Criminal Investigation and Evidence. New York: Springer-Verlag, 217-245.

Steller, M., \& Ko “hnken, G. (1989). Statement analysis: Credibility assessment of children's testimonies in sexual abuse cases. In D.C. Raskin (Ed.), Psychological methods in criminal investigation and evidence (217-245). New York, NY: Springer.

Steller, M., \& Wellershaus, P. (1996). Information enhancement and credibility assessment of child statements: the impact of the cognitive interview technique on criteria-based content analysis. In G.Davies, S.Lloyd Bostock, M.McMurran, \& C.Wilson (Eds.),Psychology, law and criminal justice: International developments in research and practice (118-126). Berlin: Walter de Gruyter. 
Stromwall, L. A. \& Granhag, P. A. (2005). Children's Repeated Lies and Truths: Effects on Adults' Judgments and Reality Monitoring Scores. Psychiatry, Psychology and Law, 12, 345-356.

Strömwall, L. A., \& Granhag, P. A. (2005). Children's repeated lies and truths: Effects on adults judgements and reality monitoring scores. Psychiatry, Psychology and Law, 12, 345-356.

Tye, M. C., Amato, S. L., Honts, C. R., Devitt, M. K., \& Peters, D. (1999).The willigness of children to lie and the assessment of credibility in an ecologically relevant laboratory setting. Applied Developmental Science, 3, 92-109.

Vrij A. (2008). Detecting lies and deceit: pitfalls and opportunities. Chichester: Wiley.

Vrij, A. (2005). Criteria-Based Content Analysis: A qualitative review of the first 37 studies. Psychology, Public Policy and Law, 11, 3-41.

Vrij, A., Akehurst, L., Soukara, S., \& Bull, R. (2004). Let me inform you how to tell aconvincing story: CBCA and reality monitoring scores as a function of age, coaching, and deception. Canadian Journal of Behavioural Science, $36,113-126$.

Vrij, A., Akehurst, L., Soukara, S., Bull, R. (2002). Will the truth come out? The effect of deception, age, status, coaching and social skills on CBCA scores. Law and Human Behaviour, 26, 261-283.

Vrij, A., Kneller, W., \& Mann, S. (2000). The effect of informing liars about Criteria- Based Content Analysis on their ability to deceive CBCA-raters. Legal and Criminological Psychology 5, 57-70.

Vrij, A., Mann, S., Kristen, S., \& Fischer, R. (2007). Cues to deception and ability to detect lies as a function of police interview styles. Law and Human Behaviour, 31, 499-518.

Wojciechowski, B. (2012). Ocena wiarygodności zeznań świadków dorosłych przy zastosowaniu psychologicznych i prawniczych kryteriów treściowych. Unpublished doctoral dissertation. University of Silesia. 